\title{
Részvétel a metamorfózisban - Avagy miért lóg egy Escher-kép a falamon?
}

\author{
Gosztonyi Márton* hozzászólása ${ }^{\star *}$
}

Ülök a lakásomban, és Maurits Cornelis Escher holland grafikus müvész Metamorphosis III. című képének reprodukcióját nézem, ${ }^{1}$ amit nagyjából tíz éve, egy hollandiai ösztöndíjról hazatérve hoztam magammal, és azóta lóg a falon. Tíz éve nézem ezt a képet, s nem jutottam hozzá közelebb. Az alkotás a metamorfózist (Görög meta- „változás” + morphe „forma”), a transzformációt, az átváltozást ragadja meg. Málovics György, Méreiné Berki Boglárka és Mihály Melinda Policy reform instead of policy transformation? (Málovics et al., 2021) címü remek cikke ugyanezzel a fogalommal foglalkozik, a részvételi akciókutatás (RAK) és a transzformáció kapcsolatát taglalja. Mint részvételi akciókutató, s mint egy Metamorfózis kép boldog tulajdonosa, a következőkben megpróbálok írni arról, hogy mit is jelent a transzformáció a RAK-ban, sorvezetőként használva Escher képét, illetve Málovics és munkatársai (2021) tanulmányát. Remélem, a folyamat végére nemcsak maga a metamorfózis fogalma lesz tisztább, hanem megértem azt is, hogy miért is lóg ez a kép a falamon.

Málovicsék absztraktjának kezdő mondatával - „Az igazságosabb és ökológiailag fenntarthatóbb társadalmak elömozdítása érdekében alapjaiban kell átalakítanunk a jelenlegi társadalmi-gazdasági rendszert" (Málovics et al., 2021, 1. o.) - messzemenően egyetértek. Úgy gondolom, hogy ez a cél akár a magyarországi színes és széles körü RAK kutatások közös forráspontjaként, céljaként is megfogalmazódhatna. Hátrányos helyzetü, kis falukban dolgozó kutatóként és fejlesztőként úgy gondolom, hogy azok a társadalmi egyenlőtlenségek, amelyek jellemzik ma, 2021-ben a társadalmunkat, sem nem fenntarthatók, sem nem igazságosak. Egy rendszer megváltoztatásához - azt gondolom azonban, egyetértve Watzlawick, Weakland és Fisch (2008) elméletével - egy rendszeren kívüli hatásnak kell megjelennie, egy olyan hatásnak, amely nem vezethető le a rendszer inherens logi-

\footnotetext{
* Gosztonyi Márton tudományos munkatárs, Budapesti Gazdasági Egyetem, Budapest LAB Vállalkozásfejlesztési Iroda. (A kézirat beérkezett: 2021.09.24. Elfogadva: 2021.11.23. Megjelent: 2022.02.15.)

"A hozzászólás Málovics és munkatársai (2021) angol nyelvű cikke alapján készült, de e lapszámban a magyar változat (Méreiné et al., 2022) kommentárjaként közöljük.

$1 \mathrm{Az}$ eredeti alkotás kiállítva: https://www.escherinhetpaleis.nl/story-of-escher/ metamorphosis-i-ii-iii/?lang=en (2022.01.06-i állapot szerint.)
} 
kájából. Egy RAK kutató megjelenése egy faluban, véleményem szerint, épp ilyen lokális rendszeren kívüli tényezőként értelmezhető, $s$ ez beindíthatja a változást, átváltozást, metamorfózist.

Még mindig Escher képét nézem. Nagyon szeretem a kép „kezdetét", azt a részt amikor formálódnak a semmiből a szavak, megjelennek vagy eltünnek, elkezdődik valami késztetés a folyamatban való részvételre. Az én kapcsolatom a képpel ott kezdődött, hogy eldöntöttem, megveszem a képet az Escher Múzeum boltjában. Életemben nem vettem még semmit múzeumshopban, meglehetősen nagy elhatározás kellett tehát ahhoz, hogy ezt megtegyem, csakúgy, mint egy transzformáció elindításához. Nem véletlen az sem, hogy mikor történt mindez: ekkor dolgoztam ki a RAK kutatásom koncepcióját, ami alapján később Magyarországon megvalósítottuk a kutatást. A folyamat kezdő lépésében még nem éreztem, de egy rendkívül fontos periódus indult el ezután az életemben. Ahhoz tehát, hogy elkezdődjön egy átalakulás, egészen biztosan szükség van egy nagy elrugaszkodásra, elszánásra, ami a kezdő energiát biztosítja a folyamat elindításakor. Ebben a kezdő energiában még csak a szándék van meg, a cél még messze van a kikristályosodástól, hol eltünik, hol újra előbukkan. Ebből eredően, ahogy Málovicsék is írják, a folyamat már a kezdeti ponttól kezdve értékekkel átitatott, és a transzformativitás egy folyamatos interakciókon keresztül létrejövő fogalomként értelmezhető (Málovics et al., 2021, 2. o.).

Egyáltalán mi is ez a történés? Egy lineáris folyamat, vagy visszacsatolási hurkokkal teletűzdelt rendszer? Ahogy Escher megálmodta a festményt, $s$ ahogy $k i$ is állították az eredetit, nem is egy lineáris csík, hanem egy kör alakban önmagába forduló kép. Eszembe ötlik, milyen nehéz is volt feltenni a falra, alig lehetett olyan falfelületet találni a lakásban, ahová egy csíkban elfért. Rákeresve az interneten azt tapasztalom, hogy egyben szinte sehol nem látható, felvágva, darabokban ábrázolják. ${ }^{2}$ Vagyis a metamorfózis képet sokféleképpen fel lehet tenni a falra, ki lehet állítani csakúgy, mint ahogy az átváltozás fogalmának is sok „kiállítási”, értelmezési lehetősége van. Lehet részegységekre darabolni, mint ahogy Bishop és munkatársai (2006) tették, $s$ részenként elemezni a lépéseit. Ám lehet nem lineáris (talán önmagába visszatérő) folyamatként is felfogni és elemezni, ahogy Málovicsék tették, megtalálva három kiváló fogalmat (autonómia, képessé tétel és szolidaritás), amelyeken keresztül közelebb juthatunk

\footnotetext{
${ }^{2}$ A kép feldarabolva: https://www.antiquesandthearts.com/mc-escher-workgoes-long-at-clars-fetches-98400 (2022.01.06-i állapot szerint.)
} 
az eseményhorizonthoz. ${ }^{3}$ Természetesen lehetne egy teljesen új történeti perspektívából kezelni a fogalmat, ahogy Castles (2001) teszi, aki a társadalmi transzformációt (social transformation) mint egy oIyan új keretrendszert értelmezi, ami a 80 -as évektől kezdve felváltotta a fejlesztési elméleteket, és megjelenését a fejlődéselmélet (development theory) kríziséhez köti. Castels értelmezésében a fogalom egy olyan holisztikus (a célvezérelt változást meghaladó) entitásként tételeződik, amiben meg tudjuk vizsgálni, hogy a globalizációs erők milyen módon hatnak a helyi közösségekre és társadalmakra (Castles, 2001).

Őszintén szólva védhetőbbnek érzem Málovicsék hozzáállását a fogalom értelmezéséhez, mint a részekre bontást vagy a történeti szemléletet. Escher képét is fel lehetne szabdalni részekre, részegységekre, mondván: Nézd! Ezen a ponton lesz sakktábla a szövegböl, a sakktáblából gyíkok lesznek, a gyíkok méhkassá változnak, amik méhekké, a méhek pedig halakká lesznek, a halakból madarak, s hirtelen egy város kerül elő, ami átalakul sakktáblává, majd újra a metamorfózis szavaivá és a semmivé... de mi értelme lenne ennek? Éppen a kép és a fogalom rendszerszerüsége csusszanna ki így a kezeink közül. A fogalom sürü leírását veszítjük így el, a folyamatot magát nem ragadjuk meg, ezzel a részekre bontó leíró értelmezéssel. Ugyanis nyitott kérdés marad ekkor, hogy pontosan jó helyen metszettük szét a képet (fogalmat)? Miért ott metszettünk, és miért nem máshol? - merülnének fel újra és újra a megválaszolhatatlan kérdések. Mindebből fakadóan sokkal célravezetőbbnek tartom rendszeren kívüli értelmező fogalmak bevezetését a megértésbe és a transzformáció ezeken keresztül való vizsgálatát.

A kérdés tehát az, hogy a Málovicsék által javasolt három fogalmon keresztül megfelelően megragadható-e a folyamat. A cikkben Málovics és munkatársai az autonómiát három nézőpontból használják (libertárius, strukturalista és feminista), mindezzel egy olyan fogalomegyüttest alkotva, amely az egyéni és társas képessé tételre koncentrál, miközben a társadalmi kontextust és a társadalmi intézmények hatásait, valamint a társadalmi helyzetet beépíti a folyamatba. Ezen túlmenően a képessé tételt olyan fogalomként ismertetik, amely a részvételi demokráciára épül, és az egyéni és a közösségi cselekvés felelősségét jeleníti meg. Végül a harmadik fogalom, a demokra-

${ }^{3}$ Málovics és munkatársai (2021) cikkükben természetesen nemcsak a fogalmi tisztázást végzik el, hanem ennek egy gyakorlati megvalósulását is bemutatják, azonban hozzászólásomban én most csak a fogalmi részt használom fel. 
tikus szolidaritás „a kedvezményezettek jogi és társadalmi egyenlöségét feltételezi, és tudatosan erősíti az egyén autonómiáját (Laville, 2014, 106. o.)" (Méreiné Berki et al., 2022, 9. o.).

A három fogalomról összegzésképpen: számomra az átalakuláshoz használt entitások alapját képezi a demokratikus szolidaritás fogalma, amely makroszinten foglalható össze abban a leegyszerüsítő kérdésben, hogy „Cselekedhetek, cselekedhetünk-e?” Erre épül az autonómia fogalma, amely mikroszinten ad választ a „Cselekedheteke?” kérdésre és arra, hogy „Rendelkezésre állnak-e azok a feltételek vagy megteremtettük-e a szükséges feltételeket a cselekvéshez?". Végül a képessé tétel fogalomegyüttese leegyszerüsítve a „Tudok-e cselekedni? Képes vagyok-e cselekedni?" kérdésekben összegezhető. Bár a fogalmaknak erről az egymásba ágyazottságáról a szerzők nem írnak, talán nem vétek értelmezési hibát, ha ezt a három fogalmat ilyen összekapcsoltságban értelmezem.

Térjünk azonban vissza egy pillanatra Escher képéhez! Megvan a fal, amire feltettem a képet, a formák folyamatosan átváltoznak (képesek átváltozni), valami azonban még hiányzik ahhoz, hogy életre keljen a kép. Ez a kifelejtett láncszem a szemlélö, a befogadó, más néven a cselekvő megértő. Mindez azért fontos, mert nélküle, s ha többen vannak, akkor nélkülük, nem létezne maga a folyamat, nem értelmeződne, nem kelne életre a kép. Ugyanezt gondolom a transzformációról a RAK folyamatban. A hármas fogalmi értelmezéssel egyetértek, azonban kiegészíteném két további entitással. Egyfelől a kívülről jött RAK kutató személyével és a kutatócsoportban részt vevő kutatókkal, akik facilitálják, elindítják, életben tartják a folyamatot, mindezzel erősen hatva a transzformáció megvalósulására. Másfelöl a folyamat komplex rendszerszintü értelmezését javasolom.

A kívülről jövő RAK kutatónak a társadalmi átalakulás iránti elkötelezettsége a RAK kutatásban a folyamat normatív aspektusa. A hatalmi aszimmetriák kezelése, az egyéni és kollektív energia, valamint a készségek és a tudás fejlesztése, így a transzformáció a kutatótól is nagymértékben függ (Blackstock et al., 2015). Ez természetesen tovább bonyolódik azzal, hogy a normatív aspektus nem pusztán a kívülröl jött RAK kutatóval kapcsolatban merül fel, hanem magával a kutatócsoportban részt vevőkkel kapcsolatban is. A kutatási folyamaton belül és a transzformációban így többféle, eltérő motiváció és álláspont hat egymásra (Cahill, 2007; Mohan, 2006). Ezek a különbségek azt is jelentik, hogy a transzformatív társadalmi változások homogén elképzelése - úgy gondolom - nem lehetséges.

A rendszerszint felöl megközelítve a fogalmi hármason alapuló elemzést pedig azzal egészíteném ki, hogy a transzformáció egy 
komplex rendszert alkot. Mindez azt jelenti, hogy nemcsak a fogalmak egymásba ágyazottságával érdemes számolnunk, hanem azzal is, hogy a transzformáció mint rendszer, egy nem lineáris, komplex entitás, amelyben a folyamat önmagában több, mint a folyamatot magyarázó változók értelmezése (Nicolis, 2012; DeLanda, 2005). ${ }^{4}$ Továbbá ez nem egy egyensúlyban lévő folyamat, hanem harmadik sorrendü komplex rendszer (Deacon, 2007). ${ }^{5}$ Ami azt jelenti, hogy az első (sztochasztikus összefüggések) és a második rendszerszintek (rendszer önszerveződése) után az átalakulás folyamatát a harmadik szinten is értelmezni kell; azaz a rendszer természetéböl fakadó radikális változások, majd azok stabilitásra jutásának értelmezését is el kell végeznünk. Mindez egy soha véget nem érő oksági hálózatot eredményez, ami épp azt a mozgást adja ki, amiben a transzformáció megragadható. Ha mindezt a saját RAK kutatásomra alkalmazom, akkor nem csupán a RAK-ot megelőző rendszert érdemes feltárni, hanem ennek a RAK következtében létrejövő transzformációját is és végül a RAK eredményeképpen létrejövő újabb struktúrának a leírását is el kell végezni.

Összefoglalva tehát úgy gondolom, hogy Málovics és munkatársai hatalmas munkát végeztek el, amikor az átváltozást, transzformációt a három fogalmon keresztül (autonómia, képessé tétel és szolidaritás) értelmezték. Ehhez kiegészítésképpen a hozzászólásomban érveltem amellett, hogy e hármas mellé fontos belevenni a folyamatban részt vevők értelmezési és motivációs perspektíváit, valamint a folyamatot, mint komplex rendszerszintü entitást érdemes megragadni. Mindezzel a folyamatot nem egy kezdő és egy végpont között lezajló lineáris folyamatként, hanem egy önmagába forduló, nem lineáris cselekvésként javaslom értelmezni. Mindebböl fakadóan megvilágíthatjuk, hogy egy RAK hatásai hogyan hozhatnak létre társadalmi transzformációt, amiben nemcsak a társadalmi forma változik meg, hanem maga a tartalom is, tehát „metacontentis” jön létre. Ezt a tartalomban és formában való örök változást ragadja meg, véleményem szerint, Escher képe is, talán ezért lóg olyan régen a falamon...

\footnotetext{
4 DeLanda (2005) „többfázisú korreláció” fogalma a komplex rendszerek esetében az okozatiság felbomlását takarja, amelyben az ok-okozati viszonyok pontos meghatározása megkérdőjeleződhet, s az összefüggések nem dualista ok-okozati párba, hanem dinamikus összefüggésrendszerbe rendeződnek.

${ }^{5}$ Deacon (2007) elméletében három sorrendű rendszerek (Three levels of emergent phenomena) szerepelnek, melyek alapján a komplex rendszerek mozgását elemezni lehet. Első sorrendű rendszerszinten egy rendszer magasabb rendü tulajdonságai ragadhatók meg, például statisztikailag vagy sztochasztikusan, míg a második sorrendü rendszerszint a rendszer önszerveződésének lokális, illetve időszakos meghatározását, a harmadik pedig a rendszer természetéből fakadó radikális változások elemzését teszi lehetővé.
} 


\section{HIVATKOZÁSOK}

Bishop, C. D.-Erezyilmaz, D. F.-Flatt, T.-Georgiou, C. D.-Hadfield, M. G.-Heyland, A.-Youson, J. H. (2006): What is metamorphosis?; Integrative and Comparative Biology 46 (6), 655-661.

Blackstock, K.-Dinnie, L.-Dilley, R.-Marshall, K.-Dunglinson, J.Trench, H.-Griffin, A. (2015): Participatory research to influence participatory governance: managing relationships with planners; Area 47 (3), 254-260.

Cahill, C. (2007): Afterword: Well positioned? Locating participation in theory and practice; Environment and Planning A 39 (12), 2861-2865.

Castles, S. (2001): Studying social transformation; International Political Science Review 22 (1), 13-32.

Deacon, T. W. (2007): Three levels of emergent phenomena; in. Murphy, A.-Stoeger, L. (szerk.): Evolution and Emergence: Systems, Organisms, Persons; Oxford University Press, Oxford, 81-110.

DeLanda, M. (2005): Intensive Science and Virtual Philosoph; Continuum. London

Laville, J-L. (2014): The social and solidarity economy: A theoretical and plural framework; in. Defourny, J.-Hulgård, L.-Pestoff, V. A. (szerk.): Social Enterprise and the Third Sector. Changing European Landscapes in a Comparative Perspective; Routledge, London, 102114.

Málovics Gy.-Méreiné Berki B.-Mihály M. (2021): Policy reform instead of policy transformation? Experiences of participatory action research (PAR) on desegregation policy in Szeged, Hungary; International Journal of Action Research 17 (1), 11-12.

Méreiné Berki B.-Málovics Gy.-Mihály M. (2022): Rendszerszintű átalakulás helyett szakpolitikai reform? A részvételi akciókutatás társadalmat átalakító ereje és annak korlátai egy megyei jogú város deszegregációs szakpolitikájának tapasztalatain keresztül; Kovász, lapszámba sorolás előtt, 1-31. https://doi.org/10.14267/kov.2022e1

Mohan, G. (2006): Beyond participation: strategies for deeper empowerment; in. Cooke, B.-Kothari, U. (szerk.): Participation: The New Tyranny?; Zed Books, London, 153-167.

Nicolis, G. (2012): Introduction to Nonlinear Science; Cambridge University Press, Cambridge

Watzlawick, P.-Weakland, J. H.-Fisch, R. (2008): Változás - A problémák keletkezésének és megoldásának elvei; Budapest, Animula 